\title{
Vascular plants diversity in short rotation coppices: a reliable source of ecosystem services or farmland dead loss?
}

\author{
Alexander Fehér ${ }^{(1)}$, \\ Lýdia Končeková (1), \\ Daniela Halmová ${ }^{(1)}$, \\ Piotr Prus ${ }^{(2)}$, \\ Zita Izakovičová (3), \\ Marian Dragoi ${ }^{(4)}$
}

\begin{abstract}
Short rotation coppices (SRCs) are a relatively new type of crop stand that is usually established on agricultural land in intensively used landscapes. However, SRCs also offer services other than the production of renewable energy. We evaluated the more complex significance of SRCs by including the other important potential ecosystem services of these stands. The objective of this paper was to evaluate the ecosystem services and disservices of SRCs by inductive (bottom-up) methods moving from the species-level to the ecosystem services on the basis of the spontaneous vascular plants diversity in SRCs. We also compared the plant-diversity-based potential ecosystem services and disservices of field SRCs, crops and forests in the same landscape in southwestern Slovakia. It was found that SRCs had an intermediate vascular plants species composition between those of forest ecosystems and agroecosystems. Among the ten evaluated ecosystem services and disservices, considering the sum of the positive and negative evaluations, SRCs had an intermediate position between the forests and arable-land vegetation. When comparing the ecosystem services of the SRCs with those of the forest ecosystems and agroecosystems, the SRCs achieved the best rating for species richness, remediation and collectables. SRCs had the worst rating for providing pasture and had the highest proportion of toxic and allergenic plants. Interestingly, SRCs achieved positive values in ecosystem services and mainly recorded the worst values in the ecosystem disservices. The direct utilization of these services and the economic balance of ecosystem services and disservices require further study.
\end{abstract}

Keywords: Bioenergy, Ecosystem Service, Farmland, Forest Ecosystem, Short Rotation Coppice

\section{Introduction \\ Humanity is looking for renewable sources of energy, one of which is the in- troduction of energy crops to farmlands. In discussions of energy crops in the much broader context of climate change, materi- als substitution (Knauf et al. 2015, Mantau 2015), energetic substitution (Werner et al. 2006, Krug et al. 2012), and offset effects (Birdsey \& Pan 2015, Albanito et al. 2016) should also be taken into consideration. These crops could be trees with short rota- tions (short rotation coppice - SRC) or dif- ferent non-woody species. Either option re-}

quires new lands and may directly or indirectly jeopardize local vascular plants species richness (Baum et al. 2012, Tscharntke et al. 2012, Bourke et al. 2014). Species richness studies on SRCs have shown different and sometimes contradictory results caused by different lengths of study periods, different scales of observation, and different definitions of biodiversity, plant diversity and species richness (Lysen \& Van Egmond 2008, Petzold et al. 2014, Mairota et al. 2016, Vanbeveren \& Ceulemans 2019). However, only substantial increases in the area covered by SRC has relevant effects
(1) Slovak University of Agriculture in Nitra, Mariánska 10, SK-949 01 Nitra (Slovakia); (2) UTP University of Science and Technology in Bydgoszcz, ul. Ks. Kordeckiego 20, PL-85-225 Bydgoszcz (Poland); (3) Institute of Landscape Ecology, Slovak Academy of Sciences, Stefanikova 3, P.O.Box 254, SK-814 99 Bratislava (Slovakia); (4) University of Suceava, 13 Universitatii str., Suceava (Romania)

@ Alexander Fehér (sandfeher@gmail.com)

Received: Feb 01, 2019 - Accepted: Jun 10, 2020

Citation: Fehér A, Končeková L, Halmová D, Prus P, Izakovičová Z, Dragoi M (2020). Vascular plants diversity in short rotation coppices: a reliable source of ecosystem services or farmland dead loss? iForest 13: 345-350. - doi: 10.3832/ifor3055-013 [online 2020-08-17]

Communicated by: Gianfranco Minotta on species richness and ecosystem services regulation (Pedroli et al. 2013, Schulze et al. 2016). The ecosystem services of SRCs can be assessed by means of DPSIR (driverpressure-state-impact-response) steps considering different scenarios and including biophysical, monetary and demand-based approaches (Lupp et al. 2015).

Assessments of the environmental, social and economic impacts of SRCs are very difficult, but models are being developed (Langeveld et al. 2012, Lupp et al. 2015). Furman et al. (2009) were not sure if the realization of bioenergy targets could be combined with the prevention of further species richness decline. Bioenergy crops may lead to further intensification of existing land uses but also to the conversion of noncropped, species-rich land into cropped or forest-like areas. On the other hand, SRC creates diverse structural and functional habitats for species diversity; the species richness of SRC was shown to be higher than that in agricultural cropland because of the longer rotation periods, low chemical input, rich spatial structure, fewer disturbances, etc. (Gustaffson 1987, EEA 2007, Fry \& Slater 2009, Dauber et al. 2010a, Dauber et al. 2010b, Verheyen et al. 2014). In landscapes with SRC, the area has a higher proportion of woodland, grassland and ruderal species (Baum et al. 2012, 
Langeveld et al. 2012), and the total vegetation cover can be 10 times higher than in the selected crops and have higher species diversity (Verheyen et al. 2014).

With increasing age, the ground flora decreases, and the vascular plants species composition shifts towards forest and nutrient-demanding species. In particular, the age of plantations and the irradiance and soil nutrient contents influence the vascular plants species composition in woody energy plantations (Baum et al. 2012). It is possible to induce greater diversity of habitats and enhance the potential for high species richness by using a mixture of willow clones and maintaining coppice coupes with differing rotations (Bennick et al. 2008). On the other hand, weed competition causes yield losses in energy crops (Sage 1999). In a mixed willow clone SRC (with three Salix clones in a row-based design), the complementarity effects shown to be larger than the selective effects, yet the overall effect of diversity on the yield was not significant (Dillen et al. 2016).

Although agricultural fields are simplified in comparison with natural ecosystems, they are still dependent on the complex natural interactions and processes that are driven by organisms. However, the amount of species richness needed for the continued resilience and productivity of agroecosystems remains a scientific challenge. The spontaneous vegetation often contains rare, endangered or vulnerable plant species and their associations. A series of methods and systems have been used to evaluate the diversity-driven value of agroecosystems (Benton et al. 2003, Fehér \& Wander 2012, Fehér et al. 2012a). These

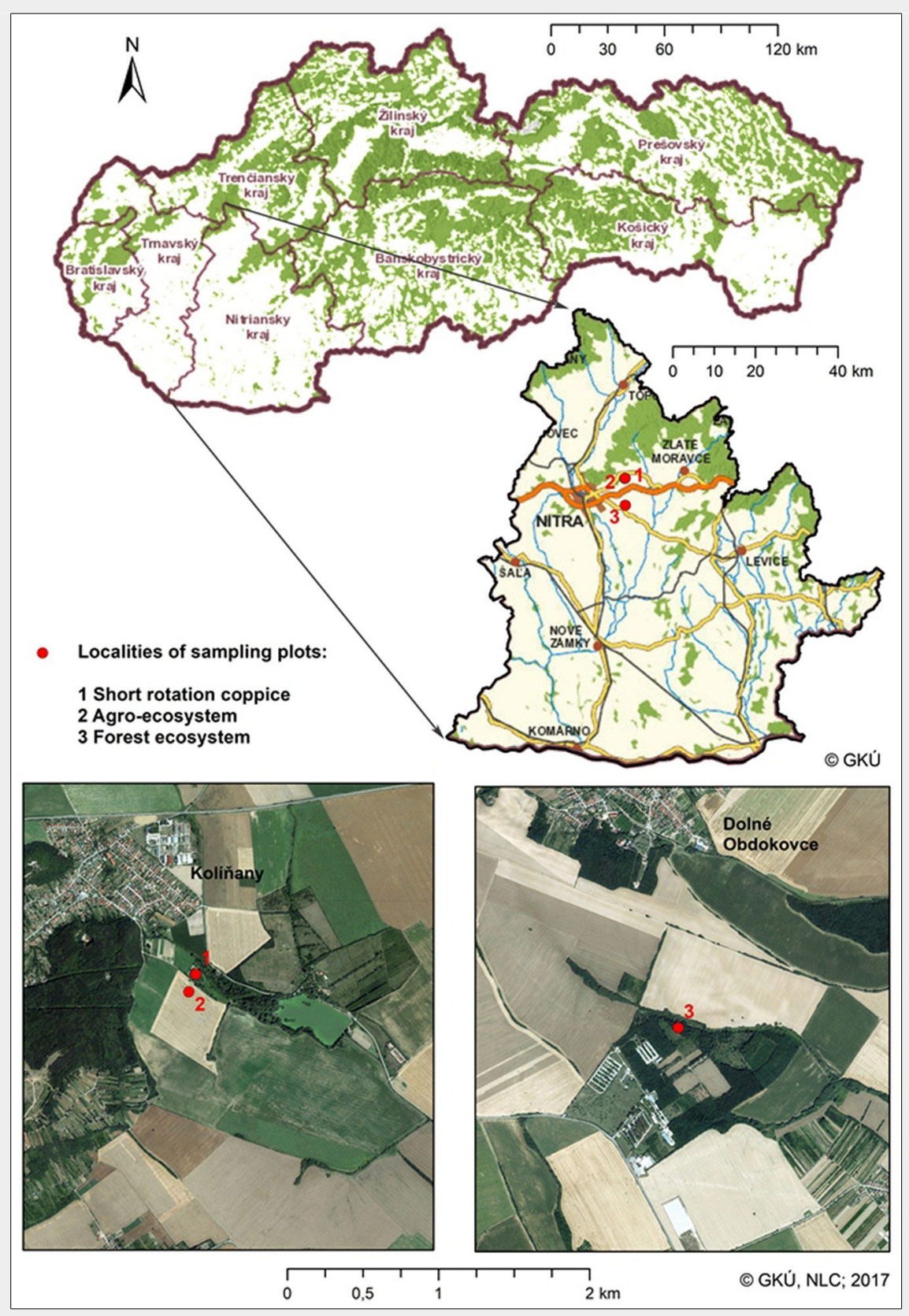

Fig. 1 - Localities of the sampling plots near Nitra, southwestern Slovakia.

methods rely on a number of approaches based on physical, biological or economic parameters. Different methods have varying degrees of importance and assess different aspects of agroecosystems (Doherty et al. 2002). There is a need to maximize diversity and minimize the harm from weed, and a set of simulation-based indicators has been developed to assess the harmfulness and the contribution to the species richness of weed communities (Mézière et al. 2015).

SRC also offers services other than the production of renewable energy (Fehér et al. 2014, Lupp et al. 2015). We evaluated the importance of SRC by including other potential ecosystem services of these stands. These benefits were balanced with negative externalities to promote greater objectivity, i.e., potential damages or loss that SRC may cause. Currently, most studies evaluate ecosystem services in a deductive way (top-down approach, e.g., by classification of ecosystem services). In contrast, the objective of this paper was to evaluate the ecosystem services and disservices of SRCs by inductive (bottom-up) methods moving from species to ecosystem services on the basis of spontaneous vascular plants diversity in SRCs. The aim of the study was to estimate the potential of the selected ecological functions to provide ecosystem services.

\section{Material and methods}

The field research was carried out in three adjacent locations (Nitra district area, southwestern Slovakia; warm and dry climate with an average annual temperature of $9.6{ }^{\circ} \mathrm{C}$ and rainfall of $560 \mathrm{~mm}$ ). The SRC stands were established in 2009 on agricultural land at the Research Centre of Slovak University in Nitra, which is located in Kolíňany ( $180 \mathrm{~m}$ a.s.l., fluvial soils - Fig. 1). The survey was performed during six consecutive growing seasons between 2009 and 2014 at 14-day intervals in three tree stands of Swedish willow varieties (Tordis, Tora, Inger). Each willow variety had a stand with a total extent of $75 \mathrm{~m}^{2}$ surrounded by continuous SRC stands to avoid edge effects, while the area of the sampling plots ( 1 sampling plot $=1$ quadrat per variety) was $25 \mathrm{~m}^{2}(2.5 \times 10 \mathrm{~m})$ per variety. The different varieties were in the same stage of the rotation (from the second year after planting until the seventh growing year; the woody biomass was harvested in the fifth year after planting). The compared crop stand (agroecosystem) was near the SRC stand at a location $100 \mathrm{~m}$ west from the mentioned SRC research plantation in Kolíñany ( $185 \mathrm{~m}$ a.s.l., fluvial soils), with 3 sampling plots of $25 \mathrm{~m}^{2}(2.5 \times$ $10 \mathrm{~m}$ ). The crops cultivated during the studied years were wheat, barley, rape (2x), maize and sunflower. The compared forest ecosystem was located in Dolné Obdokovce (190 m a.s.l., haplic luvisol), which is $6510 \mathrm{~m}$ from the SRC research plantation in Kolíňany (historically coppiced; later aged 
oak-hornbeam forest called Vel'ký háj; 3 sampling plots of $25 \mathrm{~m}^{2}, 2.5 \times 10 \mathrm{~m}$ ).

The vascular plants diversity was evaluated as the vegetation composition in an area (species richness, also called vascular flora). The plant diversity was recorded by phytocoenological reléves. A reléve is a list of the species observed in a quadrat along with estimates of their abundance (cover). In the sampling survey, the presence of species and their relative abundances were assessed using the modified Braun-Blanquet cover-abundance scale for estimating species quantities $(r,+, 1,2,3,4$ and 5 , following Braun-Blanquet 1964, Mueller-Dombois \& Ellenberg 1974). A gradient analysis of the environmental interactions of the selected energy plants ("samples") and spontaneously occurring herbs ("species") was performed by multivariate ordination methods in Canoco for Windows ${ }^{\circledast}$ ver. 4.5 (Microcomputer Power, Ithaca, NY, USA sensu Ter Braak \& Smilauer 2002). The interaction values accounting for the eigenvalues were visualized with CanoDraw for Windows ${ }^{\oplus}$ ver. 4 . The method for assessing the relative degree of the vascular plants species richness used linear and statistically indirect interactions (principal component analysis, PCA) between the coefficients of importance of the spontaneous plants (abundance $\times$ class of species persistence) and the energy plants. The class of species persistence was a classified percent share of the species in all relevés during the vegetation period, which included five categories: (1) <20\%; (2) $20.1-40 \%$; (3) 40.1-60\%; (4) 60.1-80\%; (5) 80.1-100\% (Jurko 1990). The species data had not been transformed; neither species nor samples were weighted. The samples, but not the species, have not been centered (standardized). After computing the eigenvalues and the cumulative percentage of the variances in the species data, the first two principal components were selected, and the results were presented as a biplot. A plant was considered a weed if, in any specified geographical area, its populations grew entirely or predominantly in situations markedly disturbed by man (without being deliberately cultivated - Baker 1965). The Jaccard index (Jaccard similarity coefficient) was used to gauge the similarity and diversity of the sample sets and compare the species diversity in the SRCs, forest ecosystems and agroecosystems. The index measures the similarity between finite sample sets and is defined as the size of the intersection divided by the size of the union of the sample sets as follows (eqn. 1):

$$
J(A, B)=\frac{|A| \cap|B|}{|A|+|B|-|A| \cap|B|}
$$

where $J(A, B)$ is the Jaccard index, $A$ is the number of plant species in the SRC, and $B$ is the number of plant species in the compared phytocoenosis.

The values of the ecosystems and their components were evaluated following the concept of ecosystem services, which are the benefits people obtain from ecosystems (MEA 2005). SRCs were compared with agroecosystems and forest ecosystems (see above). The following six ecosystem services and four disservices were evaluated: two nature conservation values, i.e., (i) vascular plants species richness and (ii) share of native plants sensu Medvecká et al. 2012); (iii) remediation, based on the number of tree and shrub species with remediation effects as shown in Tabs. S1-S3 (Supplementary material); (iv) collectables, i.e., harvest of beneficial plants, based on the edible plants listed in Tabs. S1-S3 and medical plants sensu Jurko (1990); (v) pasture and fodder (sensu Jurko 1990); (vi) melliferous and pollination potential (sensu Jurko 1990); (vii) weed competition, i.e., share of weeds sensu Líška et al. (2002); (viii) biological invasions (sensu Medvecká et al. 2012); (ix) toxicity (sensu Jurko 1990) and $(\mathrm{x}$ ) allergenic plants (sensu Jurko 1990). The selected services and disservices were categorized according to the Millennium Ecosystem Assessment (MEA 2005) and supplemented by categories according to the Common International Classification of Ecosystem Services, CICES (CICES 2015) considering the TEEB (Wittmer et al. 2013).

\section{Results}

The studied plant communities of the three ecosystems had different species richness values, while the plant diversity of the SRC understory resembled segetal and ruderal vegetation of disturbed areas. The Jaccard's indexes for the similarity of SRCs

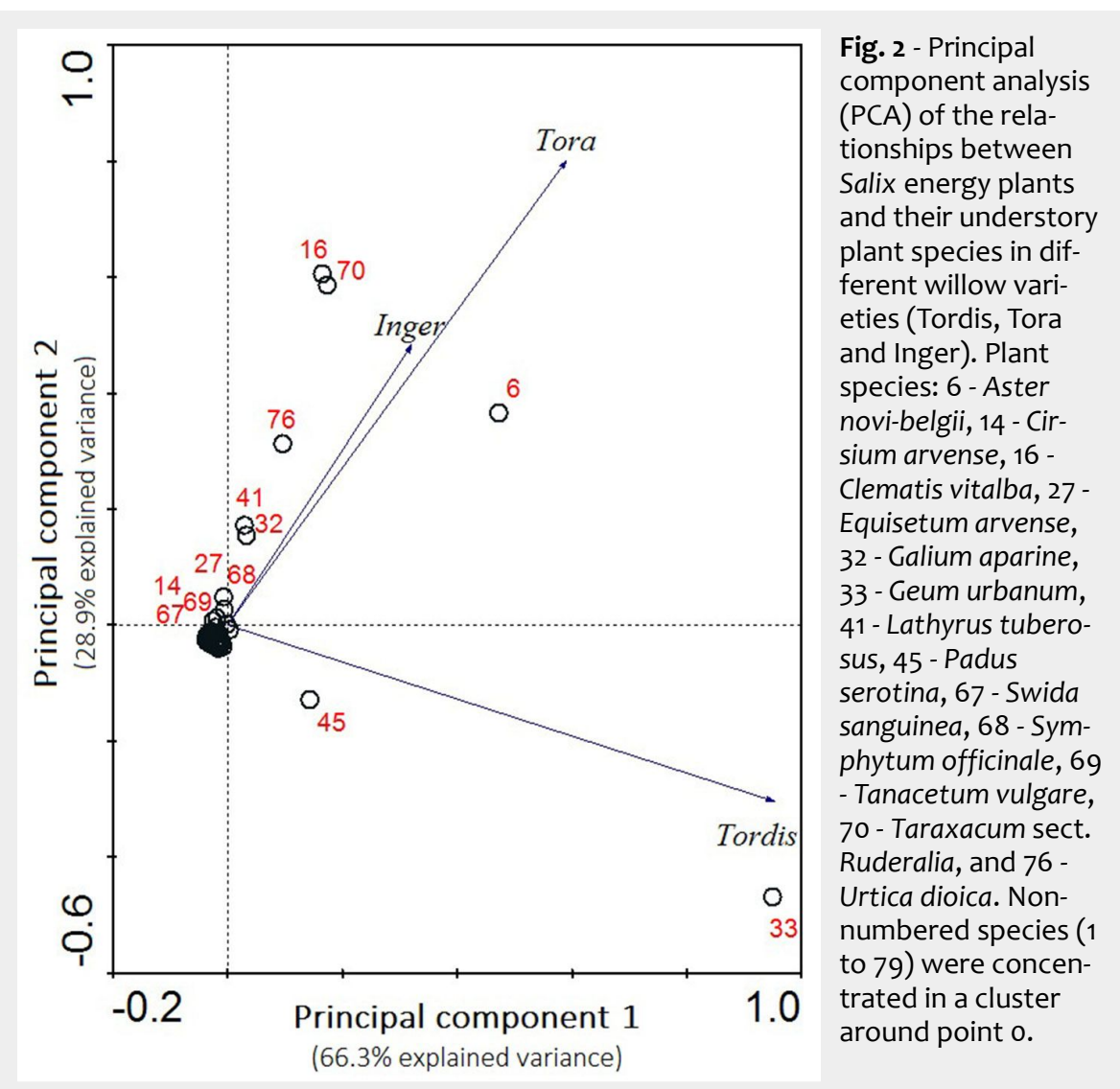

to the agroecosystems and forests was 0.28 and 0.09 , respectively. SRC vegetation included two well-distinguishable components. The fast-growing tree species form spontaneous vegetation grows, from ground to shrub height (including juvenile trees). Almost all spontaneous vascular plant species in SRCs with different Salix varieties had weedy characteristics (generalists with a wide ecological valence). These are stress tolerant species, and their propagules are often present in agroecosystems. In our research, the representative examples included Cirsium arvense, Equisetum arvense, Elytrigia repens and Convolvulus arvensis. Many juvenile shrub and woody species occurring in the understory and shrub layers also belonged to the seminatural category, e.g., Sambucus nigra, Rosa canina agg., Crataegus laevigata, Padus serotina and Swida sanguinea. The principal component analysis (PCA - Fig. 2) showed that different willow varieties did not have the same plant diversity of spontaneous vegetation. The highest number of similar accompanying species was found in the stands of Inger and Tora, while the species in the stand of Tordis were significantly different from the other two varieties. Nevertheless, relatively few plant species had a strong relationship with an individual willow variety (e.g., Geum urbanum and Padus serotina to Tordis, and Clematis vitalba and Taraxacum sect. Ruderalia to Tora). A large proportion of the spontaneously occurring species had low significance without welldefined relationships to the studied willow the edificatory tree stand, under which 


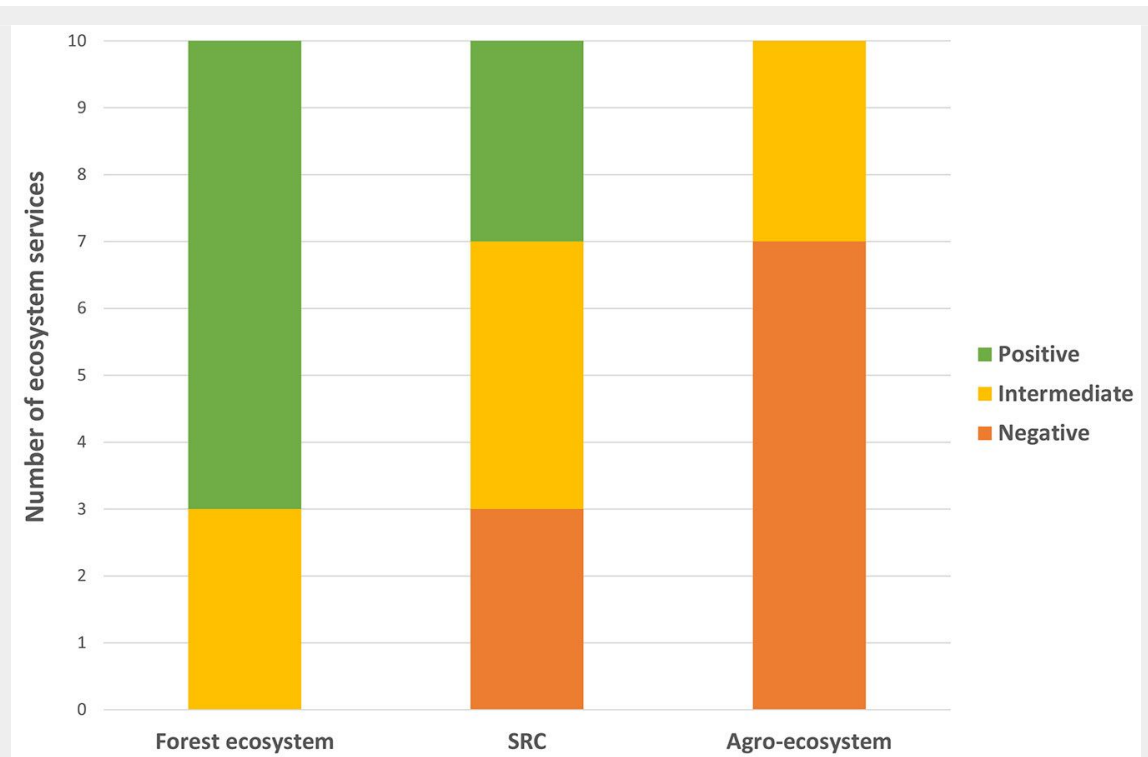

Fig. 3 - Comparison of the similarities of ten ecosystem services and disservices in SRC to the services and disservices in forest ecosystems and agroecosystems.

varieties (a cluster of species without numbers in Fig. 2). There were differences in vascular plants diversity between different years and energy trees or crops, but the basic characteristics of spontaneous vegetation were quite stable.

The presence of expansive aliens (such as Aster novi-belgii, Conyza canadensis, Stenactis annua, Galinsoga parviflora and Lycium barbarum) was interpreted as a negative competitive factor for the native species. The occurrence, growth and life cycle of the spontaneous species were affected by the ecological features of the energy crops (e.g., changes in light penetration through the canopy and light intensity near the ground during the growing season, soil water balance and the resulting water availability, nutrient competition, and growth rate), which in turn altered the phenotypic plasticity of the plant organs, the phenology of species and the vitality and development of the generative organs.

Certain potential functions (Tabs. S1-S3 in Supplementary material) have been attributed to the individual plant species by quantifying the potential of these functions by the importance of the plant species in phytocoenosis (frequency and coverage of the species in plant communities) The SRC stands ranked between the forest and crop stands in the number of positive and negative ecosystem functions (Fig. 3). When comparing the SRC ecosystem services with the forest and agroecosystem services, SRCs achieved higher richness and better ranking in remediation and col lectables. SRCs appeared to be the worst at providing pasture and fodder, as well as in the proportion of toxic and allergenic plants. The understory of vascular plants on arable land achieved the 7 worst ratings in species richness, the share of native species, remediation, collectables, melliferous plants, weed competition, and biologi- cal invasions. In contrast, the understory in the forest stands had the 7 best ratings in the share of native species, pasture and fodder, melliferous plants, weed competition, biological invasions, toxicity and allergy (Fig. 3).

\section{Discussion}

The vascular plants diversity of traditional coppice forests (e.g., oak-hornbeam forests in Central Europe) differs from the vascular plants species richness in SRC stands. The spontaneous (predominantly synanthropic) plants diversity in SRCs is more similar to the weed vegetation typical of monoculture agroecosystems (Fehér et al. 2012b, Fehér et al. 2014), but the species richness in SRCs is higher than that in arable land (Dauber et al. 2010b, Pučka et al. 2016, Vanbeveren \& Ceulemans 2019). According to our results, the diversity of vascular plant species in forests was lower than in SRCs, which contradicted Vanbeveren \& Ceulemans (2019).

Assessing the impact of SRCs on ecosystem services and disservices is difficult because they have not been monitored for an adequate period of time. During the 6 years of monitoring the vascular plants diversity in SRCs and related ecosystem services and disservices, we found that that the SRCs were functionally intermediate between the forest ecosystems and agroecosystems. This is not surprising, as SRCs are plantations on arable land and include generalists from the surrounding farmland. Woody canopy formation create conditions (particularly microclimates) for a limited number of natural forest species, and small-scale forests in the agricultural landscape contain some share of synanthropic species, as well.

From the landscape-ecological aspect, the cultivation of SRC can be considered positive when agricultural land use is inef- fective or access to agricultural land is difficult (e.g., on degraded and contaminated soils and reclaimed landfill mounds). On the other hand, with uncontrolled development, there is a risk that valuable habitats will be degraded, either in terms of nature conservation or natural resource protection, as the demand for energy plantations can expand SRC farmlands. This may lead to deforestation and the occupation of grasslands, wetlands and riparian areas, causing fragmentation and loss of species, habitats and ecosystem functions. There is a risk that growing the bioenergy industry at the expense of food products may subsequently cause a threat to food security. Plant diversity may also be impacted in SRC ecosystems by the habitat loss during harvest, when the whole tree stand is suddenly removed and the conditions (light, water, etc.) are temporarily changed.

However, many of these findings on ecosystem services are preliminary, and the issue requires further study under various soil and climatic conditions. In considering the basic work steps for the analysis and evaluation of the ecosystem services used by Grunewald \& Bastian (2015), we feel that a cost-benefit viewpoint/analysis and spatiotemporal aspects are still missing. The beneficial trends seem sufficient to compensate for the negative effects of the other impacts on human health and ecosystem quality (Rugani et al. 2015). Although we have not studied sociocultural services, it can be preliminarily noted that no direct ethical conflicts have been identified except for the loss of farmland for food production. We positively value the reintroduction of willows as an important historical landscape element with a possible traditional use (e.g., basket-weaving as a cultural value), a new land use form generating new research and education, and enrichment of the landscape structure (new patches) and view (vistas, landscape aesthetics), in accordance with Lupp et al. (2015).

It should be noted that our results reflect only the potential for providing ecosystem services based on the vascular plants species composition of the studied ecosystems (inductive approach). Their validity is limited, particularly by the phenological manifestation of species in the ecosystem. For example, melliferous species might not bloom at all in the shade of trees, or the bloom might be limited, causing low production of pollen and nectar; medicinal plants may not contain the required concentration of medicinal substances when growing under stress conditions; and weed species do not always produce effective propagules for infestation of the surrounding agroecosystems.

\section{Conclusions}

The ecosystem services evaluated by inductive (bottom-up methods from species to ecosystem services) on the basis of spontaneous plants diversity in SRCs al- 
lowed to estimate the selected ecological functions as the potential for the provision of ecosystem services. This strategy is different from the widely used deductive methods (top-down), where it is not possible to identify a wide range of potentials due to a lack of knowledge of the internal structure of ecosystems. The structure, internal hierarchy and organization of the ecosystems determines their function, which, in the case of SRC, are different from those of forests and field crops. SRCS had an intermediate vascular plants species composition and function that is between those of forests and arable crops, and from the perspective of ecosystem services and disservices, the share of both positive and negative functional values was $30 \%$ and $30 \%$, respectively (in $40 \%$ of cases, the values were intermediate). It should be noted that the weights of the studied ecological features and ecosystem services or disservices were not quantified exactly due to the lack of quantifiable information (plant population cover was considered, but the realized phenology was not evaluated). The results of the paper show that the establishment of SRCs on intensively used agricultural land and its multifunctional use provides a number of potential benefits as well as limitations. However, it was not possible to estimate the economic profits and losses caused by the evaluated ecosystem services and disservices without an economic calculation of the related costs and benefits from SRCs.

\section{Acknowledgements}

This work was supported by FP7-REGPOT2011-1 STAR-AgroEnergy "Scientific and technological advancement on research in agro-energy: an integrated approach to renewable energy generation according to sustainability criteria", COST Action FP 1301 "Innovative management and multifunctional utilization of traditional coppice forests - an answer to future ecological, economic and social challenges in the European forestry sector" (EuroCoppice) and GA FESRR 08/2017 and GA FESRR 02/2017 (Grant Agency of the FESRD, Slovak University of Agriculture in Nitra, Slovakia).

\section{References}

Albanito F, Beringer T, Corstanje R, Poulter B, Stephenson A, Zawadzka J, Smith P (2016). Carbon implications of converting cropland to bioenergy crops or forest for climate mitigation: a global assessment. Global Change Biology Bioenergy 8: 81-95. - doi: 10.1111/gcbb.12242

Baker HG (1965). Characteristics and mode of origin of weeds. In: "The Genetics of Colonizing Species" (Baker HG, Stebbins GL eds). Academic Press, New York, USA, pp. 147-172.

Baum S, Bolte A, Weih M (2012). High value of short rotation coppice plantations for phytodiversity in rural landscape. Global Change Biology Bioenergy 4: 728-738. - doi: 10.1111/j.1757-170 7.2012.01162.x

Bennick J, Holway A, Juers E, Surprenant R (2008). Willow biomass: an assessment of the ecological and economic feasibility of growing willow biomass for Colgate University. Colgate University, Hamilton, NY, USA, pp. 35. [online] URL: https://www.yumpu.com/en/document/re ad/3706283/willow-biomass-colgate-university Benton TG, Vickery JA, Wilson JD (2003). Farmland biodiversity: is habitat heterogeneity the key? Trends in Ecology and Evolution 18: 182188. - doi: 10.1016/S0169-5347(03)00011-9

Birdsey R, Pan Y (2015). Trends in management of the world's forests and impacts on carbon stocks. Forest Ecology and Management 355: 83-90. - doi: 10.1016/j.foreco.2015.04.031

Bourke D, Stanley D, O'Rourke E, Thompson R, Carnus T, Dauber J, Emmerson M, Whelan P, Hecq F, Flynn E, Dolan L, Stout J (2014). Response of farmland biodiversity to the introduction of bioenergy crops: effects of local factors and surrounding landscape context. Global Change Biology Bioenergy 6: 275-289. - doi: 10.1111/gcbb.12089

Ter Braak CJF, Smilauer P (2002). CANOCO reference manual and CanoDraw for Windows user's guide. Software for Canonical Community Ordination (version 4.5). Biometris, Wageningen, Germany and Ceské Budejovice, Czeck Republic, pp. 499. [online] URL: http:// library.wur.nl/WebQuery/wurpubs/reports/3418 85

Braun-Blanquet J (1964). Pflanzensoziologie. Grundzüge der Vegetationskunde [Plant sociology. Basics of vegetation science]. Springer Verlag, Wien-New York, pp. 865. [in German]

CICES (2015). Common International Classification of Ecosystem Services. Biodiversity Information System for Europe - BISE, Web site. [online] URL: http://biodiversity.europa.eu/maes/c ommon-international-classification-of-ecosyste m-services-cices-classification-version-4.3

Dauber J, Emmerson M, Jones M, Stout J, Finnan $J$ (2010a). Strategic overview of influences of biomass crop production on biodiversity and ecosystems services in Ireland. Simbiosys EPA, Dublin, Ireland, pp. 12. [online] URL: https:// www.tcd.ie/research/simbiosys/images/SIMBIO SYS\%20Bioenergy\%20Crops\%20Sectoral\%20Revi ew.pdf

Dauber J, Jones MB, Stout JC (2010b). The impact of biomass crop cultivation on temperate biodiversity. Global Change Biology Bioenergy 2: 289-309. - doi: 10.1111/j.1757-1707.2010.01058.x Dillen $M$, Vanhellemont $M$, Verdonckt $P$, Maes WH, Steppe K, Verheyen K (2016). Productivity, stand dynamics and the selection effect in a mixed willow clone short rotation coppice plantation. Biomass and Bioenergy 87: 46-54. - doi: 10.1016/j.biombioe.2016.02.013

Doherty S, Rydberg T, Ekbladh G, Grönlund E, Ingemarson F, Karlsson L, Nilsson S, Strid Eriksson I (2002). Ecosystem properties and principles of living systems as foundation for sustainable agriculture - critical reviews of environmental assessment tools, key findings and questions from a course process. Ekologiskt Lantbruk 32, Swedish University of Agriculture Science, Centre for Sustainable Agriculture, Uppsala, Sweden, pp. 80.

EEA (2007). Estimating the environmentally compatible bioenergy potential from agriculture. Technical report no. 12/2007, European Environment Agency, Copenhagen, Denmark, pp.
138. [online] URL: http://www.eea.europa.eu/ publications/technical_report_2007_12

Fehér A, Halmová D, Končeková L (2012a). Spontaneous associated plants in short rotation coppice: challenge for invaders. In: Proceedings of the " $7^{\text {th }}$ European Conference on Biological Invasions" [GEIB Grupo Especialista en Invasiones Biologicas eds]. Pontevedra (Spain) 12-14 Sept 2012. Grupo Especialista en Invasiones Biologicas, Leon, Spain, pp. 330.

Fehér A, Halmová D, Končeková L (2014). Evaluation of biodiversity of ground flora in short rotation coppice: positive and negative externalities. In: Proceedings of the " $222^{\text {nd }}$ European Biomass Conference and Exhibition" (Hoffmann C, Baxter D, Maniatis K, Grassi A, Helm P eds). Hamburg (Germany) 23-26 June 2014. ETA - Florence Renewable Energies, Florence, Italy, pp. 342-345.

Fehér A, Končeková L, Glemnitz M, Berger G, Pfeffer H, Herzon I (2012b). Maintaining and promoting biodiversity. In: "Sustainable Agriculture" (Jakobsson C ed). Baltic University Press, Uppsala, Sweden, pp. 371-387. [online] URL: http://www.diva-portal.org/smash/get/diva2:60 2610/FULLTEXT02

Fehér A, Wander M (2012). Assessment of sustainable land use. In: "Rural development and land use“ (Karlson I, Rydén L eds). Baltic University Press, Uppsala, Sweden, pp. 243-255. [online] URL: http://books.google.com/books? id=C4VfGN_9nHoC

Fry D, Slater F (2009). The biodiversity of short rotation willow coppice in the Welsh landscape. Aberystwyth University, Aberystwyth, Wales, UK, pp. 154. [online] URL: https://www. aber.ac.uk/en/media/departmental/ibers/resear ch/willowforwales/Biodiversity-of-src-coppicein-the-Welsh-Landscape.pdf

Furman E, Peltola T, Varjopuro R (2009). Interdisciplinary research framework for identifying research needs. Case: bioenergy-biodiversity interlinkage. The Finnish Environment 17 (Finnish Environment Institute). Edita Publishing, Helsinki, Finland, pp. 95. [online] URL: http:// orgprints.org/16403/1/intresearch.pdf Grunewald K, Bastian O (2015). Ecosystem services - concept, methods and case studies. Springer-Verlag, Berlin, Heidelberg, Germany, pp. 312. [online] URL: http://books.google.com/ books?id=fmZ1CQAAQBAJ

Gustaffson L (1987). Plant conservation aspects of energy forestry - a new type of land use in Sweden. Forest Ecology and Management 21: 141-161. - doi: 10.1016/0378-1127(87)90078-8 Jurko A (1990). Ekologické a socioekonomické hodnotenie vegetácie [Ecological and socialeconomic evaluation of vegetation]. Príroda, Bratislava, Slovak Republic, pp. 200. [in Slovakian]

Knauf M, Köhl M, Mues V, Olschofsky K, Frühwald $\mathrm{A}$ (2015). Modeling the $\mathrm{CO}_{2}$ effects of forest management and wood usage on a regional basis. Carbon Balance and Management 10: 112. - doi: 10.1186/s13021-014-0011-4

Krug J, Koehl M, Kownatzki D (2012). Revaluing unmanaged forests for climate change mitigation. Carbon Balance and Management 7 (1): 605. - doi: 10.1186/1750-0680-7-11

Langeveld H, Quist-Wessel F, Dimitriou I, Aronsson P, Baum C, Schulz U, Bolte A, Baum S, Kohn 
J, Weih M, Gruss H, Leinweber P, Lamersdorf N, Schmidt-Walter P, Berndes G (2012). Assessing environmental impacts of short rotation coppice (SRC) expansion: model definition and preliminary models. Bioenergy Research 5: 621635. - doi: 10.1007/s12155-012-9235-x

Líška E, Cernuško K, Hunková E, Otepka P (2002). Biológia burín [Weed biology]. SPU, Nitra, Slovak Republic, pp. 221. [in Slovakian]

Lupp G, Bastian O, Grunewald K (2015). Energy crop production - a complex problem for assessing ES. In: "Ecosystem Services - Concept, Methods and Case Studies " (Grunewald K, Bastian $O$ eds). Springer-Verlag, Berlin, Heidelberg, pp. 112-118.

Lysen E, Van Egmond S (2008). Climate change scientific assessment and policy analysis. Biomass assessment. Assessment of global biomass potentials and their links to food, water, biodiversity, energy demand and economy, Main report. Netherlands Environmental Assessment Agency MNP, Bilthoven, Netherlands, pp. 108. [online] URL: http://www.pbl. $\mathrm{nl} /$ sites/default/files/cms/publicaties/500102012. pdf

Mairota P, Buckley P, Suchomel C, Heinsoo K, Verheyen K, Hédl R, Terzuolo PG, Sindaco R, Carpanelli A (2016). Integrating conservation objectives into forest management: coppice management and forest habitats in Natura 2000 sites. iForest - Biogeosciences and Forestry 9: 560-568. - doi: 10.3832/ifor1867-009 Mantau U (2015). Wood flow analysis: quantification of resource potentials, cascades and carbon effects. Biomass and Bioenergy 79: 28-38. doi: 10.1016/j.biombioe.2014.08.013

MEA (2005). Ecosystems and human well-being: synthesis. A Report of the Millennium Ecosystem Assessment. Island Press, Washington, DC, USA, pp. 155. [online] URL: http://www.millen niumassessment.org/documents/document.35 6.aspx.pdf

Medvecká J, Kliment J, Májeková J, Halada L, Zaliberová M, Gojdičová E, Feráková V, Jarolímek I (2012). Inventory of the alien flora of Slovakia. Preslia 84: 257-309. [online] URL: http://www. cabdirect.org/cabdirect/abstract/20123299140 Mézière D, Petit S, Granger S, Biju-Duval J, Col- bach N (2015). Developing a set of simulationbased indicators to assess harmfulness and contribution to biodiversity of weed communities in cropping systems. Ecological Indicators 48: 157-170. - doi: 10.1016/j.ecolind.2014.07.028 Mueller-Dombois D, Ellenberg H (1974). Aims and methods of vegetation ecology. John Wiley and Sons, New York, USA, pp. 547. [online] URL: http://www.geobotany.org/library/pubs/ Mueller-Dombois1974_AimsMethodsVegEcol_ ch5.pdf

Pedroli B, Elbersen B, Frederiksen P, Grandin U, Heikkilä R, Henning Krogh P, Izakovičová Z, Johansen A, Meiresonne L, Spijker J (2013). Is energy cropping in Europe compatible with biodiversity? Opportunities and threats to biodiversity from land-based production of biomass for bioenergy purposes. Biomass and Bioenergy 55: 73-86. - doi: 10.1016/j.biombioe.2012.09.054 Petzold R, Butler-Manning D, Feldwisch N, Glaser T, Schmidt PA, Denner M, Feger KH (2014). Linking biomass production in short rotation coppice with soil protection and nature conservation. iForest - Biogeosciences and Forestry 7: 353-362. - doi: 10.3832/ifor1168-007

Pučka I, Lazdina D, Bebre I (2016). Ground flora in plantations of three years old short rotation willow coppice. Agronomy Research 14: 14501466. [online] URL: http://agronomy.emu.ee/w p-content/uploads/2016/05/Vol14_nr4_Pucka.p df

Rugani B, Golkowska K, Vázquez-Rowe I, Koster D, Benetto E, Verdonckt P (2015). Simulation of environmental impact scores within the life cycle of mixed wood chips from alternative short rotation coppice systems in Flanders (Belgium). Applied Energy 156: 449-464. - doi: 10.1016/j.ap energy.2015.07.032

Sage RB (1999). Weed competition in willow coppice crops: the cause and extent of yield losses. Weed Research 39: 399-411. - doi: 10.104 6/j.1365-3180.1999.00154.x

Schulze J, Frank K, Priess JA, Meyer MA (2016). Assessing regional-scale impacts of short rotation coppices on ecosystem services by modeling land-use decisions. PLoS One 11 (4): e0153862. - doi: 10.1371/journal.pone. 0153862 Tscharntke T, Clough Y, Thomas C, Wanger TC,
Jackson L, Motzke I, Perfecto I, Vandermeer J, Whitbread A (2012). Global food security, biodiversity conservation and the future of agricultural intensification. Biological Conservation 151: 53-59. - doi: 10.1016/j.biocon.2012.01.068

Vanbeveren S, Ceulemans R (2019). Biodiversity in short-rotation coppice. Renewable and Sustainable Energy Reviews 111: 34-43. - doi: 10.1016 /j.rser.2019.05.012

Verheyen K, Buggenhout M, Vangansbeke P, De Dobbelaere A, Verdonckt P, Bonte D (2014). Potential of short rotation coppice plantations to reinforce functional biodiversity in agricultural landscapes. Biomass and Bioenergy 67: 435442. - doi: 10.1016/j.biombioe.2014.05.021

Werner F, Taverna R, Hofer P, Richter K (2006). Greenhouse gas dynamics of an increased use of wood in buildings in Switzerland. Climatic Change 74: 319-347. - doi: 10.1007/s10584-006-0 427-2

Wittmer H, Van Zyl H, Brown C, Rode J, Ozdemiroglu E, Bertrand N, Brink P, Seidl A, Kettunen M, Mazza L, Manns F, Hundorf J, Renner I, Christov S, Sukhdev P (2013). TEEB - the economics of ecosystems and biodiversity: guidance manual for TEEB country studies. Version 1.o. UN - United Nations Environment Programme, Geneva, Switzerland, pp. 92. [online] URL: http://www.teebweb.org/media/2013/10/TEEB_ GuidanceManual_2013_1.0.pdf

\section{Supplementary material}

Tab. S1 - Species-level services and disservices in short rotation coppices.

Tab. S2 - Species-level services and disservices in forest ecosystems.

Tab. S3 - Species-level services and disservices in agroecosystems.

Appendix 1 - References list for the tree and shrub species with remediation effects and harvest of edible plants.

Link: Feher_3055@suppl001.pdf 